\title{
HOW HOTEL COMPANIES CAN FOSTER CUSTOMER SOCIABILITY BEHAVIOUR ON FACEBOOK?
}

\author{
Eglë VAIČIUKYNAITÉ ${ }^{*}$, Rimantas GATAUTIS \\ Digitalization Research Group, School of Economics and Business, \\ Gedimino str. 50, Kaunas University of Technology, Lithuania
}

Received 27 November 2017; accepted 18 June 2018

\begin{abstract}
Social network sites (hereinafter, SNSs) have become extremely popular, playing an important role in consumers' every day lives. Empowered by SNSs, the customer becomes more active and spends more time with their family, friends or companies online. Therefore, companies seek to encourage online conversations for several beneficial reasons such as maintaining relationships with their customers and achieving customer loyalty. There are no widely accepted characteristics of company messages that foster customer sociability behaviour regarding likes, comments, shares and emotion expressions on Facebook in literature. The purpose of this paper is to explore the characteristics of company messages that facilitate customer sociability behaviour on Facebook. The current study integrates content analysis and text analysis with the Linguistic Inquiry and Word Count Software (LIWC). The data were obtained from two five-star hotel brands on Facebook from 18th October 2016 to 18th October 2017. A total of 306 messages were collected. The results indicated that social messages generated more consumer likes, comments and emotional expressions on Facebook. The number of likes, comments and emotion expressions can be facilitated by images with humans. Messages accompanied with social words exhibit customer comments and emotion expressions.
\end{abstract}

Keywords: customer engagement behaviour, customer sociability behaviour, content type, emotionally rich messages, Facebook, social language.

JEL Classification: M31.

\section{Introduction}

SNSs provide different types of virtual places enabling social interactions with other users. SNSs have become a "third place" for a wide range of social interactions among customer to customer or customer to company interactions. Specifically, customers rely on these virtual places (Coelho, Oliveira, \& Almeida, 2016) and become more empowered and informed than ever before. Facebook is the world's most popular SNS (Bouchillon \& Gotlieb, 2017)

${ }^{\star}$ Corresponding author. E-mail: egle.vaiciukynaite@ktu.lt 
and has more than 1.870 million of active users in January in 2017 (Chaffey, 2017). In fact, the number of active customers on Facebook use SNSs for communication with their family, friends or companies.

Over the last years, SNSs have also provided new ways for companies to communicate with their consumers. Companies can interact with their current and potential customers through different types of messages on Facebook (Luarn, Lin, \& Chiu, 2015; Coelho et al., 2016). These messages may include emotionally rich text and photos, animated pictures, videos and other material. Therefore, companies seek to facilitate interactions with customers on SNSs for beneficial outcomes such as receiving more information about customer wishes and needs, develop a closer relationship with customers, increasing traffic on company websites, creating brand awareness, and consumer loyalty (Nobre \& Silva, 2014). In particular, the results of the study by Gamboa and Gonçalves (2014), showed that Facebook enhances customer loyalty through trust, customer satisfaction, perceived value and commitment. Furthermore, it highlighted that these relations are stronger for fans than non-fans of the company (Gamboa \& Gonçalves, 2014). Therefore, researchers and practitioners have been trying to understand which characteristics of company messages result in customer engagement on Facebook.

Customer engagement, or customer engagement behaviour (CEB), has been widely analysed by academics (Beckers, van Doorn, \& Verhoef, 2017; Dolan, Conduit, Fahy, \& Goodman, 2016; Gavilanes, Flatten, \& Brettel, 2018; Harmeling, Moffett, Arnold, \& Carlson, 2017; Hollebeek, Glynn, \& Brodie, 2014; Schivinski, Christodoulides, \& Dabrowski, 2016; Yang, Lin, Carlson, \& Ross, 2016; Yoon, Li, Ji, North, Hong, \& Liu, 2018; van Doorn, Lemon, Mittal, Nass, Pick, Pirner, \& Verhoef, 2010); however, there is still no general agreement among researchers about its definition and conceptualisation. Importantly, the term "engagement" can be seen as a behavioural construct or even an affective/cognitive and behavioural one (Schivinski et al., 2016). The behavioural approach is mainly used in the most recent customer engagement literature (see Beckers et al., 2017; Leung, Tanford, \& Jiang, 2017). Thus, the behavioural conceptualization of CEB follows recommendations by Harmeling et al. (2017) because it captures its implicit and explicit meaning. Therefore, this study uses the behavioural manifestation of consumer engagement behaviour and is defined as "customer sociability behaviour".

The term "sociability" denotes the opportunity to interact with other users or socialise through features in the virtual environment (Keenan \& Shiri, 2009). Thus, the behavioural manifestation of CEB is defined as "the customer's behavioural manifestations toward a brand or firm, beyond purchase, resulting from motivational drivers" (van Doorn et al., 2010, p. 253). However customer sociability behaviour includes eight customer responses on Facebook company pages and these are: sending a signal of approval (e.g. a Like), commenting, sharing or express an emotional reaction (e.g. Love, Angry, etc.) (Turnbull \& Jenkins, 2016).

Past research investigated the relationship between various characteristics of company messages and customer sociability behaviour on Facebook. For instance, several studies examined the impact of various features of company messages on customer sociability behavior (Cvijikj \& Michahelles, 2013; Tafesse, 2015; Kim, Spiller, \& Hettche, 2015; Luarn et al., 2015; 
Coelho et al., 2016). These research studies have analysed various sectors, e.g. food/beverage brands, automotive companies, beauty, fashion design and paid attention to short-term analyses. However, the hospitality industry is different from goods, therefore it encompasses four characteristics: "intangibility, inseparability, heterogeneity, and perishability" (Kwok \& Yu, 2016, p. 312). This implies that there is a lack of research into hospitality.

The aforementioned empirical research on the characteristics of company messages on Facebook has used the result of qualitative research and does not integrate quantitative text analysis. Indeed, company messages include text accompanied with emotional cues (e.g. emojis) and is widely used to express emotion on Facebook (Hsieh \& Tseng, 2017). These emotional cues may augment feelings of warmth and personableness (Luangrath, Peck, \& Barger, 2017). Therefore, text analysis research is applied in psychology and involves various contexts including Facebook, text messenger (Bazarova, Taft, Choi, \& Cosley, 2012; Tausczik \& Pennebaker, 2010; Settanni \& Marengo, 2015). Thus, the most recent study by Leek, Houghton, and Canning (2017) has shown that different linguistic content of messages are associated with greater behavioural engagement on Twitter. Moreover, this study do not focus on social words. Meanwhile Labrecque and Swani (2017) have investigated linguistic style of company message and their impact across customer likes, comments, and shares on Facebook. Importantly, previous studies have identified the importance of social content of company messages on CEB on Facebook (Kwok \& Yu, 2013; Tafesse \& Wien, 2017a). Nonetheless, we still do not know enough about the text used in company messages (e.g. social language) on a company Facebook page. However this discussion shows that this study is original and innovative because it integrates quantitative social word analysis in text.

To date, there is a lack of in-depth analysis of hospitality companies' message features and their relation to customer sociability behaviour on Facebook. Additionally, responding to calls by Kabadayi and Price (2014), Leung, Law, Van Hoof and Buhalis (2013), Tafesse and Wien (2017a) and Marketing Science Institute [MSI] (2016), this study extends previous studies by including sharing behaviour, emotion reactions (e.g. Wow) and thus, features of company messages such as social language. The purpose of this paper is to investigate the characteristics of company messages that encourage customer sociability behaviour regarding likes, comments, shares and emotion reactions on company Facebook pages. This study combines content analysis and text analysis performed with LIWC. Thus, this study uses an interdisciplinary approach and a one-year analysis of hotel company messages. Finally, the study fills the aforementioned research gaps and in the literature. Therefore, this study broadens the research discussion on features of company messages of hotels that foster customer sociability behaviour on Facebook.

Following the literature review of the characteristics of the company messages and customer sociability behaviour on a company's Facebook page, the next section will discuss the key findings in this area. The second section presents research methodology and results of the study. The final section concludes the current study and provides limitations. Recommendations for future research are presented. 


\section{Literature review and hypotheses}

\subsection{Customer sociability behaviour}

Companies can develop social relationships with consumers and strengthen these bonds through company messages on Facebook pages. These messages can be accompanied with text, photos, or videos which may attract attention of customers and their subsequent responses. Moreover, customers' responses to brand messages include two types of customer participation such as passive (e.g. viewing) or active (e.g. liking). Passive customer participation does not include customer behaviour such as liking or commenting on a message. An active customer participation represents actual customer behaviour and includes liking, commenting, sharing and emotion reactions, or multiples of them. Consequently, these active customer contributions may encourage others to socialise through messages on a company Facebook page.

Sociability is defined as the ability for users to interact with others (Keenan \& Shiri, 2009) or companies through social features and the customer demonstrates social behaviour on Facebook (Dimitriu \& Guesalaga, 2017). Hence, customer sociability behaviour refers to customer behavioural manifestation toward a company, beyond purchase, and comes from motivational drivers (i.e. social) (Van Doorn et al., 2010; Meshi, Tamir, \& Heekeren, 2015; Dolan et al., 2016; Dolan, Conduit, Fahy, \& Goodman, 2017). More specifically, customer sociability behaviour may include various kinds of customer actions such as liking, commenting, sharing and emoji reactions on Facebook (Yang et al., 2016; Turnbull \& Jenkins, 2016). For example, emotion reactions include Love, Haha, Wow, Sad, Angry. Moreover, a type of customer action depends on a company message and is related to customer needs, motives or even interpersonal relationships with a company/brand (Ashley \& Tuten, 2015).

Importantly, a company may engage a customer in different ways, such as liking, commenting, and sharing. Liking behaviour allows customers to indicate their liking in one click for the company's messages, sharing this information with their social network. In addition, liking behaviour might be recognised as "affective" customer response (Kim et al., 2015). In contrast, commenting behaviour enables customer to express their opinions and feelings on a company's Facebook page (Kabadayi \& Price, 2014) and requires more consumer effort. The sharing behaviour describes "the extent to which users exchange, distribute and receive content" (Kietzmann, Hermkens, McCarthy, \& Silvestre, 2011, p. 245). However, it allows customers to share the company's content with their social network on their Facebook wall. Going one step further, a high number of customer shares and comments on company message may present the high degree of customer involvement that customers spend their time expressing opinions (Sabate, Berbegal-Mirabent, Cañabate, \& Lebherz, 2014) compared to liking behaviour. In a similar vein as consumer likes, consumer emotion reaction enables customers to express their feelings to company messages with a single click.

The aforementioned consumer actions can be categorised based on psychological implication (Kim \& Yang, 2017), which explains that different customer actions may present diverse levels of involvement. For instance, customer shares are categorised as the highest level, the comments present the medium level and linking behaviour or emotion reactions as the lowest level. Therefore, consistent with previous studies (Kim et al., 2015; Stepaniuk, 2017), this 
study uses customer likes, comments, shares and emotion reactions as customer sociability behaviour on company Facebook pages. In light of this, customer sociability behaviour might be affected by various features of messages.

\subsection{Content type of company messages}

The content type of company messages involves four categories: informational, entertainment, remuneration and social messages. Informational company messages contain information about the brand or its products and services. In addition, informational messages may be defined as self-oriented content (Kim et al., 2015) or sales and marketing (Kwok \& Yu, 2013). In particular, messages containing information about the brand or products encourage customer motivation to participate and consume (De Vries, Gensler, \& Leeflang, 2012). Recent findings have shown that information related to company messages generates more likes in comparison with social and entertainment messages (Luarn et al., 2015). In contrast, the study has shown that messages containing informational content exhibit a lower number of customer likes and comments (Kwok \& Yu, 2013). Hence, the study predicts that customer demonstrate different customer sociability behaviour than with other types of company messages.

Entertainment messages are a type of message that does not refer to the information about products/services, brand, and company. These messages include funny videos, anecdotes, teasers or slogans (Cvijikj \& Michahelles, 2013). Moreover, a company message for entertainment purposes may facilitate customer motivation to participate and consume (De Vries et al., 2012). A number of previous studies have shown that entertainment company messages generate more customer comments and shares (Cvijikj \& Michahelles, 2013; Luarn et al., 2015). Furthermore, studies have found that entertaining messages were identified as the most influential on customer sociability behaviour on a company's Facebook page (Cvijikj \& Michahelles, 2013). Hence, the study proposes that customers tend to foster their sociability behaviour in comparison with other company messages.

Remuneration company messages include specific information which is directly or indirectly associated with various benefits for customers including special promotions, trials and other offers (Cvijikj \& Michahelles, 2013; Luarn et al., 2015; Kwok \& Yu, 2016). These messages can encourage social contagion process and in turn, generate customer sociability behaviour on a company's Facebook page (Tussyadiah, Kausar, \& Soesilo, 2015). An example of remuneration messages is as follows: "[...] share this message and wait for the 9th of October, when the winner will be announced!”. Moreover, previous studies have shown diverse results that company remuneration messages exhibit a higher number of customer likes (Luarn et al., 2015), comments (Cvijikj \& Michahelles, 2013), or lose their customer participation on that company's Facebook page (Chan \& Guillet, 2011). Thus, the current study proposes that customers demonstrate more diverse customer actions than they engage with the other types of company messages.

Social messages contain information that usually occurs in personal interaction and may include information such as shared personal experience, sociable events (e.g. Birthdays) or small talk. Therefore, social messages are designed to develop social interaction with consumers (Kwok \& Yu, 2013), which is the "essence and value" of the SNSs (Chan \& Guillet, 2011, p. 360). Moreover, social messages include discussions, questions, events, social 
causes, various statements that provide the ability for consumers to socialise (Kwok \& Yu, 2013; Ashley \& Tuten, 2015; Luarn et al., 2015).

Tafesse and Wien (2017a) have provided a comprehensive categorisation of social messages that includes four common themes (e.g. personal brand content, current events, brand community, customer relationship). An example of social messages is as follows: "Have a colourful week!", “This is how we celebrate International boss day" (followed by pictures). Indeed, emphasis of social message is on consumer interaction and enable deeper customer relationships (Tafesse \& Wien, 2017a). According to past studies in food services, social messages generate more likes and comments from customers on Facebook (Kwok \& Yu, 2013). The findings suggest that social messages foster diverse customer sociability behaviour in terms of likes, shares, comments and emotional reactions.

Following the discussion above, different content types of company message demonstrate diverse customer social actions in terms of customer likes, comments, shares and emotional reactions. Thus, consistent with the previous study by Luarn et al. (2015), the following hypothesis is proposed:

H1: Diverse content types of company messages (e.g., informational, entertainment, remuneration, social) lead to different degrees of customer sociability behaviour outcomes (like, comment, share and emotion reactions).

Emotionally-rich images present an image containing one or more expressive human face(s) displaying emotions. These emotions differ on a level of analysis based on diverse aspects of emotions. For example, a company can create messages accompanied with a high arousal of happiness or neutral expression in human faces. In fact, this discrete emotion (e.g. happiness) is classified into a positive category of emotion (valence) and has a higher activity (Laros \& Steenkamp, 2005). On the contrary, the neutral emotion indicates lack of emotions, e.g. lack of fear, happiness, or anger (Lewinski, 2015). Therefore, there are still many aspects of "emotion" (Izard, 2010), but researchers widely use a discrete emotion approach (Ha, Kwon, Cha, \& Joo, 2017; Lewinski, 2015).

The use of emotional-rich images in messages may be important for customer sociability behaviour on SNSs. Previous work in the package design of juice emphasises the connection between smiling facial expressions and consumer joy and positive attitudes (Berg, Söderlund, \& Lindström, 2015). However, the study by Guerini, Staiano and Albanese (2013) has shown that images containing faces have a higher probability of being appreciated or commented on Google+. Furthermore, most recent works emphasise the connection between emotion in images used in messages and user sociability behaviour regarding likes and comments on Instagram (Ha et al., 2017; Bakhshi, Shamma, \& Gilbert, 2014). More specifically, a study has revealed that images with happiness and neutral expressions have a positive influence on user likes on Instagram (Ha et al., 2017). Therefore, because it is unclear what relationship emotionally-rich images may have with customer sociability behaviour on company Facebook pages, the study poses the following hypothesis:

H2: Different company images (e.g. with humans and non-humans) lead to diverse degrees of customer sociability behaviour outcomes (like, comment, share and emotion reactions). 
Social language is one of the various language cues which can be used to augment the meaning of company messages. Social language includes diverse social cues (or words) such as we, team, interaction which is specific to the social interaction (Tausczik \& Pennebaker, 2010). For instance, social interaction between company and consumer is more specific than between customers. In fact, company and customer prefer this social interaction-oriented process (Sheth, 1976), which includes different types of content messages and text accompanied with various (social) words.

Recently, researchers have started to analyse social language on individual friendships on SNSs (Sosik \& Bazarova, 2014). Another study by Kwok and Yu (2016) has investigated indicative keywords associated with promotional messages and social messages, as well as identifying top indicative keywords. For instance, promotional messages involve key words such as "win" and "winners" (marketing campaign), "special" and "available" (promotions), "gift" and "new" (product descriptions) (Kwok \& Yu, 2016). In contrast, top social words include "team", "favourite", "many", "her", "thanksgiving” (Kwok \& Yu, 2016). In turn, the content of social messages include forms of questions, events, feedback, and weather. Still, to this date, there is no study on how a social language of messages is related to customer sociability behaviour. Hence, the next hypothesis is as follows:

H3: There is a relationship between the presence of social words in a message and customer sociability behaviour (like, comment, share and emotion reactions).

The proposed three hypothesis are visualised in Figure 1.

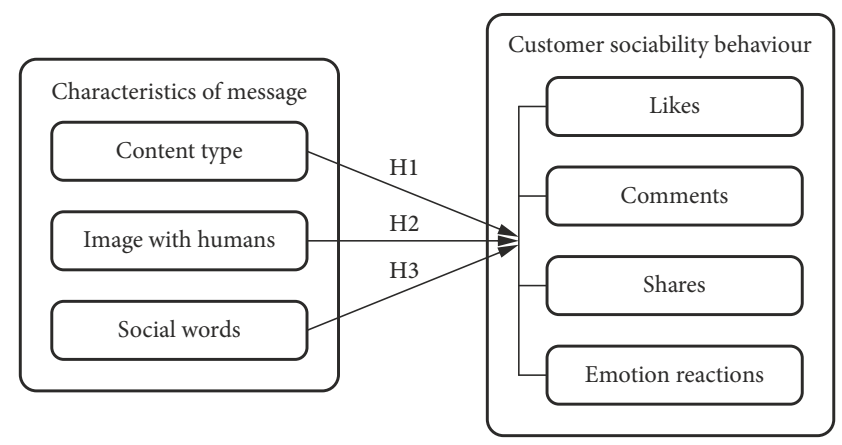

Figure 1. The hypothesised relationship between characteristics of a message and customer sociability behaviour outcomes on Facebook (source: own elaboration)

\section{Research methodology}

The study combines content analysis and text analysis performed with LIWC. The content analysis was used to investigate the relationship between characteristics of company message and customer sociability behaviour (like, comment, share and emotion reactions) (to test hypothesis H1, H2). The text analysis using LIWC was applied to count social words (H3).

Data Collection. Consistent with previous studies (Kim et al., 2015; Leung et al., 2017), this study used Facebook as the medium because it is the most popular SNS among customers and companies. The current study used the service-based company Facebook pages and 
had an advantage over prior studies. For instance, many studies have explored productoriented company messages on Facebook pages (Luarn et al., 2015; Coelho et al., 2016). Moreover, this sample frame followed certain criteria including (1) the existence of an official company Facebook page, (2) English language for communication (Cvijikj \& Michahelles, 2013), (3) an active company Facebook page.

This study collected company messages of two international five-star hotels on Facebook from 18th October 2016 to 18th October 2017. The data was collected using Facebook Graph API. However, the extracted results included all information related to this study: the content and the media type of a message and number of customer behavioural actions liking, commenting, sharing and emotion expressions (e.g. Love). A total of 306 messages were selected for further investigation. Importantly, this study does not include several messages in Lithuanian language.

Regarding the relationship between social language usage in company messages and customer sociability behaviour, this study followed the guidelines of previous studies (Bazarova et al., 2012) and prepared the text messages for linguistic analysis using the Mac version of LIWC 2015. This software identifies social words in language (text) use and its validation was tested with previous studies (Tausczik \& Pennebaker, 2010; Sosik \& Bazarova, 2014; Settanni \& Marengo 2015; Luangrath et al., 2017). Specifically, the most recent study has investigated 37 word categories by using LIWC (Leek et al., 2017) on Twitter but do not involve social words (i.e. we). In our context, the social word category is selected for its relevance to this study. Thus, previous studies have indicated the importance of social content of company messages on Facebook (see Kwok \& Yu, 2013; Tafesse \& Wien, 2017a).

Data Coding. The content analysis was performed by two independent coders who had no knowledge about the research hypotheses. The coders were trained to categorise several company messages. Later on, the coders organized the content of the message into four categories. Intercoder reliability was approximately 0.9 , within the accepted range of $0.66-0.95$ based on Su, Reynolds, and Sun (2015).

\section{Operationalisation of the independent variables}

\section{Content type of message}

Following previous studies (Kwok \& Yu, 2013; Luarn et al., 2015), the content type of company messages was coded into four categories: informational, entertainment, remuneration, and social messages. Informational company messages contain content about the various services of a hotel, such as rooms, conference halls, restaurants, spa and other information which is related marketing activities (e.g. company events/festivals). Entertainment company messages include various funny videos, teasers and anecdotes. More specifically, company messages accompanied with another companies' activities which can entertain the analysed company's customers was considered as entertainment. For example, the brand entitled 52 kadrai organized a photo (and video) session on the hotel roof. Remuneration company messages include promotions, trials, online coupons, discounts that facilitate customer behavioural responses (e.g. share and win). In contrast, social company messages are designed to encourage conversation with a company's customers and contain information which is 
not directly related to the company promotions or services. For instance, company messages may include questions, statements, experience sharing, social initiatives and different greetings (e.g. "Happy Boss day", "Company Anniversary”, "Happy Easter”). Thus, social messages include information about company's team and their achievements, or fan messages.

\section{Emotionally-rich image}

This study adapted types of images based on Ha et al. (2017). The images were coded into two categories: images with humans and images without humans.

\section{Social language}

The selection of the LIWC social category was based on previous works (Sosik \& Bazarova, 2014). This category with higher scores shows a greater number of social words per message. Specifically, the current study used only one linguistic category (e.g. social words) in order to test a hypothesis.

\section{Operationalisation of the dependent variable}

\section{Customer sociability behaviour}

Consistent with previous studies (Cvijikj \& Michahelles, 2013; Kim et al., 2015; Coelho et al., 2016; Turnbull \& Jenkins, 2016), this study operationalized customer sociability behaviour into four dependent variables such as likes, comments, shares and emotion reactions. The emoji reaction includes five emotion reactions such as Love, Haha, Wow, Sad and Angry.

\section{Results}

This section provides descriptive statistics of different measures. The number of fans on both hotel brands was 1884 and 8386 on 10 October 2017. With regard to the content type of hotel messages, informational (158; 51.6 percent) and social messages were used the most frequently (117; 38.2 percent), followed by entertainment ( $8 ; 2.6$ percent), and remuneration ( $23 ; 7.5$ percent) messages posted by hotel companies. Regarding social words of brand messages, the total number of messages accompanied with social words was $244(79,74$ percent), the average number $(\mathrm{M})$ per post was 11.20 (SD $=0.457)$. More specifically, different customer sociability measures were influenced by several characteristics of company messages and are provided in the next section.

\section{Hypothesis test}

Following the previous work by Tafesse and Wien (2017b), the study used the analysis of variance (ANOVA) to test the proposed hypothesis. Distributions of dependent variables (customer sociability behaviour: likes, shares, comments and emotion reactions) were heavily skewed. Consistent with Luarn et al. (2015), the logarithms of the values were used in further analysis. 


\section{Hypothesis $\mathrm{H} 1$}

According to $\mathrm{H} 1$, different content types of message generate different degrees of customer sociability behaviour (like, comments, share and emotion reactions). The results showed that $\mathrm{H} 1$ was partially supported (Like: $\mathrm{F}(3 ; 302)=16.19>5.42, \mathrm{p}<0.001$; Comment: $\mathrm{F}(3 ; 302)=6.751>5.42, \mathrm{p}<0.001$; Share: $\mathrm{F}(3 ; 302)=0.932<5.42, \mathrm{p}>0.001$; Emoji: F (3; $302)=16.953>5.42, \mathrm{p}<0.001)($ Table 1$)$.

The results indicated that customers were more likely to like social messages (Like: $\mathrm{M}=3.913, \mathrm{SD}=0.881$ ), entertainment (Like: $\mathrm{M}=3.913, \mathrm{SD}=0.708$ ) and remuneration (Like: $\mathrm{M}=3.149, \mathrm{SD}=0.729)$ types. In addition, the results indicated that customers are more likely to comment on social messages (Comment: $\mathrm{M}=0.657, \mathrm{SD}=0.736$ ) and entertainment (Comment: $\mathrm{M}=0.554, \mathrm{SD}=0.847$ ). Furthermore, the results showed that entertainment (Share: $\mathrm{M}=0.842, \mathrm{SD}=1.059$; Emoji: $\mathrm{M}=1.609, \mathrm{SD}=0.518$ ) and social messages generated a significantly larger level of sharing and emotional reactions (Share: $\mathrm{M}=0.803$, $\mathrm{SD}=0.862$; Emoji: $\mathrm{M}=1.441, \mathrm{SD}=0.787$ ). More specifically, remuneration messages may not motivate consumers to express their emotional reactions (e.g., Love, Haha, Wow). Therefore, $\mathrm{H} 1$ was supported.

Table 1. ANOVA analysis for the effect of content type

\begin{tabular}{|c|c|c|c|c|c|c|}
\hline $\begin{array}{c}\text { Dependent } \\
\text { variable }\end{array}$ & Type of content & $\mathrm{n}$ & M & SD & $\mathrm{F}$ & $\mathrm{P}$ \\
\hline \multirow{4}{*}{ Like } & Informational & 158 & 3.103 & 1.105 & \multirow{4}{*}{16.19} & \multirow{4}{*}{$0.000^{*}$} \\
\hline & Entertainment & 8 & 3.913 & 0.708 & & \\
\hline & Remuneration & 23 & 3.149 & 0.729 & & \\
\hline & Social & 117 & 3.913 & 0.881 & & \\
\hline \multirow{4}{*}{ Comment } & Informational & 158 & 0.312 & 0.521 & \multirow{4}{*}{6.751} & \multirow{4}{*}{$0.000^{*}$} \\
\hline & Entertainment & 8 & 0.554 & 0.847 & & \\
\hline & Remuneration & 23 & 0.344 & 0.808 & & \\
\hline & Social & 117 & 0.657 & 0.736 & & \\
\hline \multirow{4}{*}{ Share } & Informational & 158 & 0.678 & 0.766 & \multirow{4}{*}{0.932} & \multirow{4}{*}{0.426} \\
\hline & Entertainment & 8 & 0.842 & 1.059 & & \\
\hline & Remuneration & 23 & 0.559 & 0.637 & & \\
\hline & Social & 117 & 0.803 & 0.862 & & \\
\hline \multirow{4}{*}{ Emoji } & Informational & 158 & 0.869 & 0.766 & \multirow{4}{*}{16.953} & \multirow{4}{*}{$0.000^{*}$} \\
\hline & Entertainment & 8 & 1.609 & 0.518 & & \\
\hline & Remuneration & 23 & 0.626 & 0.59 & & \\
\hline & Social & 117 & 1.441 & 0.787 & & \\
\hline
\end{tabular}

Note: $\mathrm{n}$, number of messages; $\mathrm{M}$, mean; SD, standard deviation; F, f-value, $\mathrm{p}, \mathrm{p}$-value ${ }^{\star} \mathrm{p}<0.001$.

\section{Hypothesis $\mathrm{H} 2$}

Human images and images without any humans were accumulated and used to test the proposed hypothesis $\mathrm{H} 2$. The results indicated that $\mathrm{H} 2$ was statistically significant to likes, comments and emoji (Like: F $(1 ; 224)=6.727>6.635 ; \mathrm{p}<0.01$; Comment: $\mathrm{F}(1 ; 224)=$ 
$13.084>6.635$; p < 0.01; Emoji: $\mathrm{F}(1 ; 224)=13.262>6.635)$ but not to shares (Share: $\mathrm{F}(1$; $224)=0.418<6.635 ; \mathrm{p}>0.01$ ) (Table 2). With regard to expectations, customers were more likely to like, comment, share and express their emotions with human image. Therefore $\mathrm{H} 2$ was partially supported.

Table 2. ANOVA analysis for the effect of image type $(n=226)$

\begin{tabular}{|c|c|c|c|c|c|c|}
\hline $\begin{array}{c}\text { Dependent } \\
\text { variable }\end{array}$ & Type of image & $\mathrm{n}$ & M & SD & $\mathrm{F}$ & $\mathrm{P}$ \\
\hline \multirow{2}{*}{ Likes } & No human & 125 & 3.416 & 0.865 & \multirow{2}{*}{6.727} & \multirow{2}{*}{$0.01^{\star}$} \\
\hline & Human & 101 & 3.746 & 1.049 & & \\
\hline \multirow{2}{*}{ Comment } & No human & 125 & 0.319 & 0.568 & \multirow{2}{*}{13.084} & \multirow{2}{*}{$0.00^{*}$} \\
\hline & Human & 101 & 0.638 & 0.755 & & \\
\hline \multirow{2}{*}{ Share } & No human & 125 & 0.741 & 0.749 & \multirow{2}{*}{0.418} & \multirow{2}{*}{0.52} \\
\hline & Human & 101 & 0.806 & 0.757 & & \\
\hline \multirow{2}{*}{ Emoji } & No human & 125 & 0.978 & 0.749 & \multirow{2}{*}{13.262} & \multirow{2}{*}{$0.00^{*}$} \\
\hline & Human & 101 & 1.359 & 0.822 & & \\
\hline
\end{tabular}

Note: $\mathrm{n}$, number of messages; $\mathrm{M}$, mean; $\mathrm{SD}$, standard deviation; $\mathrm{F}, \mathrm{f}$-value, $\mathrm{p}, \mathrm{p}$-value ${ }^{\star} \mathrm{p}<0.01$.

\section{Hypothesis $\mathrm{H} 3$}

The findings showed that there were two significant positive and modest correlations: (1) between social words and customer commenting behaviour (Comments: $r=0.127, p<0.05$ ), (2) between social words and customer emotion expressions (Emoji: $r=0.2, p<0.01$ ) as shown in Table 3 . Therefore, H3 was only partially supported.

Table 3. Correlation among variables $(\mathrm{N}=244)$

\begin{tabular}{|c|c|c|c|c|c|}
\hline Variables & Social words & Like & Comments & Shares & Emoji \\
\hline Social words & - & 0.109 & $0.127^{\star}$ & -0.027 & $0.2^{* *}$ \\
\hline Like & 0.109 & - & $0.586^{* *}$ & $0.460^{* *}$ & $0.753^{* *}$ \\
\hline Comments & $0.127^{\star}$ & $0.586^{* *}$ & - & $0.317^{\star *}$ & $0.546^{* *}$ \\
\hline Shares & -0.027 & $0.460^{* *}$ & $0.317^{\star *}$ & - & $0.376^{* *}$ \\
\hline Emoji & $0.2^{\star *}$ & $0.753^{\star *}$ & $0.546^{\star *}$ & $0.376^{* *}$ & - \\
\hline
\end{tabular}

Note: ${ }^{*}$ Correlation is significant at the $0.05 ;{ }^{* *}$ Correlation is significant at the 0.01 .

\section{Discussion}

This study employed an interdisciplinary approach and investigated the influence of various characteristics of company messages including content type, image type, and text language on customer sociability behaviour. The research findings reveal that the effect of various characteristics of messages on customer sociability behaviour on Facebook differs. Most importantly, this study reveals some novel insights which can be considered important to service company communication on Facebook. For instance, in contrast to previous study by Luarn 
et al. (2015), the findings indicated that social messages exhibited the most customer sociability behaviour in terms of likes, shares and emotion reactions on Facebook. Thus, Luarn et al. (2015) have highlighted that social messages are associated with comments. In a similar vein, this the findings of this study confirmed this relationship. In other words, this might be explained by the fact that customers of service companies prefer to view social messages on Facebook more than other message types.

Importantly, social and entertainment aspects of message can motivate consumers to share and express their emotions on companies' Facebook pages. Thus, a possible explanation could be that entertainment messages are not related to companies/brands, while consumers are interested in companies/brands and are consistent with the previous research (De Vries et al., 2012). Moreover, these results imply that the communication of service companies should focus on social and entertainment messages more than informational, remuneration messages. Marketers highly recommended to post social or entertainment messages on a hotel company's Facebook page.

With regard to image type of message, research findings reveal that hotel companies actively posted images, and these results are consistent with the previous studies (Kim et al., 2015). Additionally, the number of customer likes, comments and emotion reactions can be enhanced by images with humans. Moreover, an image with a human face is easier to process because it requires less effort to extract than another type of image (e.g. abstract imagery) (Chang \& Chen, 2017). On the other hand, images with humans may act as an emotional trigger and facilitate automatic customer responses. Surprisingly, the study results do not confirm the significant relationship between an image with an human and customer sharing behaviour. This study does not explore the images with a human across different types of company messages. It might be explained that informational messages used human images and customer do not share this type of content. As a result, marketers who want to engage their audience are recommended to post messages with images including humans.

Interestingly, this study's findings do not show a significant relationship between the diverse content types and image type of message and consumer sharing behaviour on Facebook. A possible explanation might be related to emotionality of a content of message, i.e., high or low-arousal emotions. For instance, previous study findings have indicated that content accompanied with a high-arousal positive (i.e. awe) or negative emotion (i.e. anxiety) are associated with sharing behaviour (Berger \& Milkman, 2012). On the contrary, message content that induces low-arousal emotions is less associated with sharing behaviour.

Another explanation might be related to cultural differences of consumers/followers of a luxury brand in Lithuania. Our findings suggest tentatively that consumers of luxury hotel brand do not intend often to share company's messages on Facebook, but we cannot generalize these results across all luxury hotel brands in Lithuania. In contrast to our results, a recent study results indicated that luxury hotels showed the biggest average number of likes and shares per messages (see more: Leung et al., 2017).

With regard to the social language of company messages, a message with social words increases consumer commenting behaviour and emotion reactions on Facebook. These results are partly consistent with previous work by Kwok and Yu (2013) in the food service because their findings indicated that social messages (content) generate more customer likes 
and comments. Marketers highly recommended providing messages with social words on Facebook. In summary, the study findings reveal several new insights in research of the characteristics of company messages and customer sociability behaviour on Facebook.

\section{Conclusions}

This study provides several novel insights into the existing literature by analysing characteristics of company messages, which encourage customer sociability behaviour on Facebook. Moreover, the current study integrates an interdisciplinary methodology and focuses on two samples of service-based companies. Furthermore, the study presents a one-year message analysis and reveals a fresh contribution into marketing literature. In fact, the research proposes three types of characteristics of company messages that foster customer sociability in terms of likes, comments, shares, and emotion reactions on companies' Facebook pages. The features of company messages include content type, image type and textual content.

The first notable conclusion from this study is that social messages (content type) stimulate the highest level of customer sociability behaviour in comparison with other types of company messages. In addition, the smallest number of likes, shares, comments is indicated by the informational type of messages. Therefore, these results imply that marketers should post social and entertainment messages in order to enhance customer sociability on Facebook. With regard to image type, the study findings show that images with humans increase the number of likes, comments and emotion expressions (e.g. Love, Haha, Wow, etc.). Hence, marketers should use more social messages and images with humans in order to foster customer sociability on Facebook. Finally, the intriguing conclusion of this study is that company messages with social words are powerful and generate customer commenting behaviour, and thus emotion expressions. These findings reveal that marketers should focus on social text in posting messages on company Facebook pages.

This study reveals novel insights into customer sociability behaviour on a company Facebook pages, but has several limitations. First, the study only provides analysis of three characteristics of company messages on Facebook, and does not represent other characteristics such as media type or other types of text. For instance, an emotional text analysis includes positive and negative words. The second limitation is that the study examined two hotel brands, but it does not present the whole hospitality sector. Therefore, study findings cannot be generalized for the entire hospitality sector. Thirdly, focusing on the results that there is a relationship between social words and commenting and emotional reactions. Therefore, further research in this domain is recommended.

Moreover, emotional reactions might be provided with some new insights about customer reactions to a particular company's messages and enhance that company's communication strategy. In essence, these findings shed light on the features of company messages, especially with regard to the content type of the messages, text and image-based for further research, analysing customer sociability behaviour on Facebook. Future research may enhance these study findings by incorporating media type of messages, emotionality text and generalise the results for hospitality industry companies on Facebook as a whole. 
The findings discussed in the above sections should be considered with some limitations. First, this study has limitations related to Facebook customer demographic backgrounds. Therefore, these results cannot be generalised to both, younger (e.g. Millennials, Gen Z) and older generations (Baby Boomers) of customers. Moreover, customers with different age may show diverse behaviour on SNSs. For instance, EkStyvén and Foster (2018) have noted that Millennial and Gen Z consumers are showing an increasing part of tourists and have a propensity to share the content on SNSs. However the future studies on customer sociability behaviour on SNSs should consider customer characteristics (e.g. age, gender, personality type). Additionally, future studies can make a comparison between different generation of customer (e.g. Millennials and Baby Boomers) and characteristics of company messages, as well as customer sociability behaviour on SNSs.

This study examined the selective five-star hotel brands on Facebook while other categories of hotel brands can fail to confirm these results. However, future studies should include a wide range of hotel brands and test the relationship between different characteristics of company message and customer sociability behaviour on Facebook. Furthermore, the future studies can imply other types of SNS such as Twitter or Instagram and test these findings.

In addition, the study findings can encourage hotel managers and social media coordinators to prepare customer engagement strategies that enhance the activity of customer. Thus, the study reveals that different content types of messages influence customer sociability behaviour. For instance, social messages can enhance customer comments. Therefore, hotel managers and social media coordinators can decide which type of customer sociability behaviour they seek to facilitate.

\section{Acknowledgements}

I would like to thank late professor Rimantas Gatautis who encouraged me to pursue this study. I appreciate his inspiration and guidance for the research idea which will be developed as professor R. Gatautis would have expected. Lastly, I would like to thank PhD student Valentas Gružauskas from Economics and Business School from Kaunas University of Technology (KTU) for some data collection help.

\section{References}

Ashley, C., \& Tuten, T. (2015). Creative strategies in social media marketing: an exploratory study of branded social content and consumer engagement. Psychology \& Marketing, 32(1), 15-27. https://doi.org/10.1002/mar.20761

Bakhshi, S., Shamma, D. A., \& Gilbert, E. (2014). Faces engage us: photos with faces attract more likes and comments on Instagram. In Proceedings of the 32nd Annual ACM Conference on Human Factors in Computing Systems. ACM. https://doi.org/10.1145/2556288.2557403

Bazarova, N. N., Taft, J. G., Choi, Y. H., \& Cosley, D. (2012). Managing impressions and relationships on Facebook: self-presentational and relational concerns revealed through the analysis of language style. Journal of Language and Social Psychology, 32(2), 121-141.

https://doi.org/10.1177/0261927X12456384 
Beckers, S. F., van Doorn, J., \& Verhoef, P. C. (2017). Good, better, engaged? The effect of companyinitiated customer engagement behavior on shareholder value. Journal of the Academy of Marketing Science, 46(3), 366-383.

Berg, H., Söderlund, M., \& Lindström, A. (2015). Spreading joy: examining the effects of smiling models on consumer joy and attitudes. Journal of Consumer Marketing, 32(6), 459-469. https://doi.org/10.1108/JCM-03-2015-1356

Berger, J., \& Milkman, K. L. (2012). What makes online content viral?. Journal of Marketing Research, 49(2), 192-205. https://doi.org/10.1509/jmr.10.0353

Bouchillon, B. C., \& Gotlieb, M. R. (2017). Making them count: Facebook sociability for optimizing the accumulation of social capital. Social Science Computer Review, 35(3), 299-318. https://doi.org/10.1177/0894439315626422

Chaffey, D. (2017, September 9). Global social media research summary 2017 [Web log post]. Smart Insights. Retrieved from http://www.smartinsights.com/social-media-marketing/social-mediastrategy/new-global-social-media-research/

Chan, N. L., \& Guillet, B. D. (2011). Investigation of social media marketing: how does the hotel industry in Hong Kong perform in marketing on social media websites?. Journal of Travel \& Tourism Marketing, 28(4), 345-368. https://doi.org/10.1080/10548408.2011.571571

Chang, C. T., \& Chen, P. C. (2017). Cause-related marketing ads in the eye tracker: it depends on how you present, who sees the ad, and what you promote. International Journal of Advertising, 36(2), 336-355.

Coelho, R. L. F., Oliveira, D. S. D., \& Almeida, M. I. S. D. (2016). Does social media matter for post typology? Impact of post content on Facebook and Instagram metrics. Online Information Review, 40(4), 458-471. https://doi.org/10.1108/OIR-06-2015-0176

Cvijikj, I. P., \& Michahelles, F. (2013). Online engagement factors on Facebook brand pages. Social Network Analysis and Mining, 3(4), 843-861. https://doi.org/10.1007/s13278-013-0098-8

De Vries, L., Gensler, S., \& Leeflang, P. S. (2012). Popularity of brand posts on brand fan pages: an investigation of the effects of social media marketing. Journal of Interactive Marketing, 26(2), 83-91. https://doi.org/10.1016/j.intmar.2012.01.003

Dimitriu, R., \& Guesalaga, R. (2017). Consumers' social media brand behaviors: uncovering underlying motivators and deriving meaningful consumer segments. Psychology \& Marketing, 34(5), 580-592. https://doi.org/10.1002/mar.21007

Dolan, R., Conduit, J., Fahy, J., \& Goodman, S. (2017). Social media: communication strategies, engagement and future research directions. International Journal of Wine Business Research, 29(1), 2-19. https://doi.org/10.1108/IJWBR-04-2016-0013

Dolan, R., Conduit, J., Fahy, J., \& Goodman, S. (2016). Social media engagement behaviour: a uses and gratifications perspective. Journal of Strategic Marketing, 24(3-4), 261-277. https://doi.org/10.1080/0965254X.2015.1095222

EkStyvén, M., \& Foster, T. (2018). Who am I if you can't see me? The "self" of young travellers as driver of eWOM in social media. Journal of Tourism Futures, 4(1), 80-92. https://doi.org/10.1108/JTF-12-2017-0057

Gamboa, A. M., \& Gonçalves, H. M. (2014). Customer loyalty through social networks: lessons from Zara on Facebook. Business Horizons, 57(6), 709-717. https://doi.org/10.1016/j.bushor.2014.07.003

Gavilanes, J. M., Flatten, T. C., \& Brettel, M. (2018). Content strategies for digital consumer engagement in social networks: why advertising is an antecedent of engagement. Journal of Advertising, 47(1), 4-23. https://doi.org/10.1080/00913367.2017.1405751

Guerini, M., Staiano, J., \& Albanese, D. (2013, September 8-14). Exploring image virality in google plus, In Proceedings of 2013 IEEE International Conference on Social Computing (SocialCom). Alexandria, VA, USA. https://doi.org/10.1109/SocialCom.2013.101 
Ha, Y. I., Kwon, S., Cha, M., \& Joo, J. (2017, 15-18 May). Fashion conversation data on Instagram. In Proceedings of 2017 ICWSM International AAAI Conference on Web and Social Media. Montreal, Canada.

Harmeling, C. M., Moffett, J. W., Arnold, M. J., \& Carlson, B. D. (2017). Toward a theory of customer engagement marketing. Journal of the Academy of Marketing Science, 45(3), 312-335. https://doi.org/10.1007/s11747-016-0509-2

Hollebeek, L. D., Glynn, M. S., \& Brodie, R. J. (2014). Consumer brand engagement in social media: conceptualization, scale development and validation. Journal of Interactive Marketing, 28(2), 149165. https://doi.org/10.1016/j.intmar.2013.12.002

Hsieh, S. H., \& Tseng, T. H. (2017). Playfulness in mobile instant messaging: examining the influence of emoticons and text messaging on social interaction. Computers in Human Behavior, 69, 405-414. https://doi.org/10.1016/j.chb.2016.12.052

Izard, C. E. (2010). The many meanings/aspects of emotion: definitions, functions, activation, and regulation. Emotion Review, 2(4), 363-370. https://doi.org/10.1177/1754073910374661

Kabadayi, S., \& Price, K. (2014). Consumer-brand engagement on Facebook: liking and commenting behaviors. Journal of Research in Interactive Marketing, 8(3), 203-223. https://doi.org/10.1108/JRIM-12-2013-0081

Keenan, A., \& Shiri, A. (2009). Sociability and social interaction on social networking websites. Library Review, 58(6), 438-450. https://doi.org/10.1108/00242530910969794

Kietzmann, J. H., Hermkens, K., McCarthy, I. P., \& Silvestre, B. S. (2011). Social media? Get serious! Understanding the functional building blocks of social media. Business Horizons, 54(3), 241-251. https://doi.org/10.1016/j.bushor.2011.01.005

Kim, C., \& Yang, S. U. (2017). Like, comment, and share on Facebook: how each behavior differs from the other. Public Relations Review, 43(2), 441-449. https://doi.org/10.1016/j.pubrev.2017.02.006

Kim, D. H., Spiller, L., \& Hettche, M. (2015). Analyzing media types and content orientations in Facebook for global brands. Journal of Research in Interactive Marketing, 9(1), 4-30. https://doi.org/10.1108/JRIM-05-2014-0023

Kwok, L., \& Yu, B. (2013). Spreading social media messages on Facebook an analysis of restaurant business-to-consumer communications. Cornell Hospitality Quarterly, 54(1), 84-94. https://doi.org/10.1177/1938965512458360

Kwok, L., \& Yu, B. (2016). Taxonomy of Facebook messages in business-to-consumer communications: what really works?. Tourism and Hospitality Research, 16(4), 311-328. https://doi.org/10.1177/1467358415600214

Labrecque, L. I., \& Swani, K. (2017). Does linguistic style in social media communications impact consumer engagement? An abstract. In M. Stieler (Ed.). Proceedings of the 2016 Academy of Marketing Science (AMS) Annual Conference Creating Marketing Magic and Innovative Future Marketing Trends, 18-21 May 2016, Orlando, Florida (pp. 597-598). Springer. https://doi.org/10.1007/978-3-319-45596-9_112

Laros, F. J., \& Steenkamp, J. B. E. (2005). Emotions in consumer behavior: a hierarchical approach. Journal of Business Research, 58(10), 1437-1445. https://doi.org/10.1016/j.jbusres.2003.09.013

Leek, S., Houghton, D., \& Canning, L. (2017). Twitter and behavioral engagement in the healthcare sector: an examination of product and service companies. Industrial Marketing Management. Retrieved from https://www.sciencedirect.com/science/article/abs/pii/S0019850117301128. https:// doi.org/10.1016/j.indmarman.2017.10.009

Leung, D., Law, R., Van Hoof, H., \& Buhalis, D. (2013). Social media in tourism and hospitality: a literature review. Journal of Travel \& Tourism Marketing, 30(1-2), 3-22.

https://doi.org/10.1080/10548408.2013.750919 
Leung, X., Tanford, S., \& Jiang, L. (2017). Is a picture really worth a thousand words? An experiment on hotel Facebook message effectiveness. Journal of Hospitality and Tourism Technology, 8(1), 19-38. https://doi.org/10.1108/JHTT-08-2016-0039

Lewinski, P. (2015). Automated facial coding software outperforms people in recognizing neutral faces as neutral from standardized datasets. Frontiers in Psychology, 6, 1-6. https://doi.org/10.3389/fpsyg.2015.01386

Luangrath, A. W., Peck, J., \& Barger, V. A. (2017). Textual paralanguage and its implications for marketing communications. Journal of Consumer Psychology, 27(1), 98-107. https://doi.org/10.1016/j.jcps.2016.05.002

Luarn, P., Lin, Y. F., \& Chiu, Y. P. (2015). Influence of Facebook brand-page posts on online engagement. Online Information Review, 39(4), 505-519. https://doi.org/10.1108/OIR-01-2015-0029

Marketing Science Institute (MSI). (2016). Research Priorities 2016-2018. Marketing Science Institute, Boston, MA. Retrieved from http://www.msi.org/uploads/articles/MSI_RP16-18.pdf

Meshi, D., Tamir, D. I., \& Heekeren, H. R. (2015). The emerging neuroscience of social media. Trends in Cognitive Sciences, 19(12), 771-782. https://doi.org/10.1016/j.tics.2015.09.004

Nobre, H., \& Silva, D. (2014). Social network marketing strategy and SME strategy benefits. Journal of Transnational Management, 19(2), 138-151. https://doi.org/10.1080/15475778.2014.904658

Sabate, F., Berbegal-Mirabent, J., Cañabate, A., \& Lebherz, P. R. (2014). Factors influencing popularity of branded content in Facebook fan pages. European Management Journal, 32(6), 1001-1011. https://doi.org/10.1016/j.emj.2014.05.001

Schivinski, B., Christodoulides, G., \& Dabrowski, D. (2016). Measuring consumers' engagement with brand-related social-media content: development and validation of a scale that identifies levels of social-media engagement with brands. Journal of Advertising Research, 56(1), 64-80. https://doi.org/10.2501/JAR-2016-004

Settanni, M., \& Marengo, D. (2015). Sharing feelings online: studying emotional well-being via automated text analysis of Facebook posts. Frontiers in Psychology, 6, 1-7. https://doi.org/10.3389/fpsyg.2015.01045

Sheth, J. N. (1976). Buyer-seller interaction: a conceptual framework. Advances in Consumer Research, 3, 382-386.

Sosik, V. S., \& Bazarova, N. N. (2014). Relational maintenance on social network sites: how Facebook communication predicts relational escalation. Computers in Human Behavior, 35, 124-131. https://doi.org/10.1016/j.chb.2014.02.044

Stepaniuk, K. (2017). Blog content management in shaping pro recreational attitudes. Journal of Business Economics and Management, 18(1), 146-162. https://doi.org/10.3846/16111699.2017.1280693

Su, N., Reynolds, D., \& Sun, B. (2015). How to make your Facebook posts attractive: a case study of a leading budget hotel brand fan page. International Journal of Contemporary Hospitality Management, 27(8), 1772-1790. https://doi.org/10.1108/IJCHM-06-2014-0302

Tafesse, W. (2015). Content strategies and audience response on Facebook brand pages, Marketing Intelligence \& Planning, 33(6), 927-943. https://doi.org/10.1108/MIP-07-2014-0135

Tafesse, W., \& Wien, A. (2017a). A framework for categorizing social media posts. Cogent Business \& Management, 4(1), 1-22. https://doi.org/10.1080/23311975.2017.1284390

Tafesse, W., \& Wien, A. (2017b). Using message strategy to drive consumer behavioral engagement on social media. SSRN Electronic Journal. Retrieved from https://ssrn.com/abstract=3025392

Tausczik, Y. R., \& Pennebaker, J. W. (2010). The psychological meaning of words: LIWC and computerized text analysis methods. Journal of Language and Social Psychology, 29(1), 24-54.

https://doi.org/10.1177/0261927X09351676 
Turnbull, S., \& Jenkins, S. (2016). Why Facebook reactions are good news for evaluating social media campaigns. Journal of Direct, Data and Digital Marketing Practice, 17(3), 156-158. https://doi.org/10.1057/dddmp.2015.56

Tussyadiah, I. P., Kausar, D. R., \& Soesilo, P. K. (2015). The effect of engagement in online social network on susceptibility to influence. Journal of Hospitality \& Tourism Research, 42(2), 201-223. https://doi.org/10.1177/1096348015584441

van Doorn, J., Lemon, K. N., Mittal, V., Nass, S., Pick, D., Pirner, P., \& Verhoef, P. C. (2010). Customer engagement behavior: theoretical foundations and research directions. Journal of Service Research, 13(3), 253-266. https://doi.org/10.1177/1094670510375599

Yang, S., Lin, S., Carlson, J. R., \& Ross, J. W. T. (2016). Brand engagement on social media: will firms' social media efforts influence search engine advertising effectiveness?. Journal of Marketing Management, 32(5-6), 526-557. https://doi.org/10.1080/0267257X.2016.1143863

Yoon, G., Li, C., Ji, Y., North, M., Hong, C., \& Liu, J. (2018). Attracting comments: digital engagement metrics on Facebook and financial performance. Journal of Advertising, 47(1), 24-37.

https://doi.org/10.1080/00913367.2017.1405753 